\title{
Impact of community participation in adaptive wildlife resources management at Mole National Park, Ghana
}

\author{
Benjamin Makimilua Tiimub ${ }^{1 *}$, Braimah Gbolo $^{2}$, Richard Wonnsibe Tiimob ${ }^{3}$, Ernestina \\ Laatman Tiimob ${ }^{4}$, Vida Kumedzro ${ }^{5}$ \& Elisha Tiimob ${ }^{6}$ \\ University of Education, Winneba, Ashanti-Mampong Campus, Ghana ${ }^{1,2,5}$ \\ Science Department, Savelugu Senior High School, Ghana ${ }^{3}$ \\ Business Senior High School (BISCO), Ghana ${ }^{4}$ \\ Regional Maritime University, Ghana ${ }^{6}$ \\ benmakimit@yahoo.com ${ }^{1 *}$,gbolobraimah@yahoo.com ${ }^{2}$,wtiimob@gmail.com ${ }^{3}$, tinalaat@gmail.com ${ }^{4}$, \\ kvidish@gmail.com ${ }^{5}$, elishadat1998@gmail.com ${ }^{6}$
}

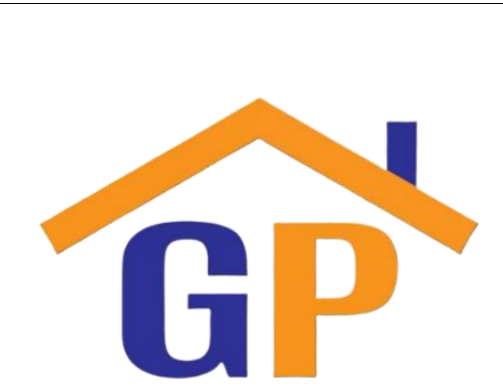

Article History

Received on 14 September 2020

$1^{\text {st }}$ Revision on 26 September 2020

$2^{\text {nd }}$ Revision on 28 September 2020

Accepted on 29 September 2020

\begin{abstract}
Purpose: Wildlife resources constitute indispensable nature's strongholds for human livelihoods strategies in forest, savanna zones across Ghana and the worldwide although, it often engendered conflicts. Impact of community participation on adaptive wildlife resources management was strategically assessed at Mole National Park.
\end{abstract}

Research methodology: 60 randomly selected park environs residents were interviewed for valid responses using semistructured questionnaires.

Findings: High wildlife products demand has transformed bush meat into lucrative business through poaching by thousands of youths and adults, causing habitat destruction and sharp wildlife population decline. Hunters, poachers, middlemen, restaurant operators constituted game-trade-market-value chain.

Limitations: Funding subjectivity reduced scope of the study to only few communities in dry season. Temptation to reject the questionnaires on suspicion of force evacuation plots against some park adjoining villages was later refuted. Hence, recovery rate was $100 \%$.

Contribution: We recommend that Wildlife Division of the Forestry Commission should strengthen synergies on community participation in adaptive wildlife management by coopting educational interventions that positively influence indigenous behaviors through seminars, workshops, face-to-face interactions. This will better define the rights, roles, responsibilities of key partners towards resolving communal wildlife conflicts.

Keywords: Community participation, Wildlife management, Park sustainability, Poaching, Game-trade-market-value chain

How to cite: Impact of community participation in adaptive wildlife resources management at Mole National Park, Ghana. Journal of Sustainable Tourism and Entrepreneurship, 1(2), 139-149.

\section{Introduction}

Wildlife resources, usually perceived as bush meat in the perspective of hunters or recreational wildlife for amateur tourists have constituted nature's strongholds for very important livelihoods strategies of communities of both transitional forests, and savanna zones across Ghana and in the World at large (Rilley \& Rile, 2005). Wildlife is hunted mostly for food and for commercial purposes (Treves, 
2007). Some local communities attach a strong cultural importance to the resource, for example some traditional societies around the park who are predominantly Muslims do not kill and eat the bush pig (Potamochoerus larvatus) because they believe it once led a Muslim hunter to water body when he badly needed water to drink (Danso \& Mason, 1993). Although these societies have a strong cultural regard for animals, there exist no organized structure to manage it (Abonge, 1999). Wildlife has been exploited in the Mole Reserve from time immemorial as a common property solution (source with almost all hunting activities being carried out illegally). The hunters operate in it without permits using unregistered guns and unconventional trapping equipment. In the olden days, hunting involved the use of local materials and the catch was mostly for household consumption. Overtime, traditional hunting has given way to more sophisticated hunting techniques. Individual hunters set as many as three hundred traps to increase their chances of catch (Danso \& Mason, 1993).

Another major contributory factor to wildlife loss in the area is habitat destruction through bush fires and large-scale forest clearance for subsistence farming and population growth. Human demonography and reserve size have been identified to predict wildlife extinction in West Africa (Brashares et al., 2001). The bush meat trade employs both men and women of youth and adult ages. The user group market chain as described by Ambrose-Orji (1997) is made up of hunters, middlemen (retailers) and pepper soup sellers. The hunters group comprises mainly young men, and two categories of hunters are identified: part time hunters (who have other occupations and only carry out hunting on occasional basis) mostly for home consumption, and full-time hunters - as professionals who invest most of their time and resources in the hunting profession. These hunters hunt for economic reasons and will move from place to place in search of wildlife. The chain is so organized to an extent that restaurant owners and pepper soup sellers even finance most of the hunting by professional hunters. The middlemen include both men and women who buy from the hunters and re-sell to the public either as smoked meat or in its original fresh form. The groups also contribute to the financing in the process from the adjacent communities in Larabanga and Damongo. Pepper soup sellers (restaurant operators) are exclusively women who prepare the meat and sell to the public as pepper soup dishes (AmbroseOrji, 1997). Approximately, ninety-three (93) large and medium sized (body weight-3kg) mammals have been recorded around the Mole National Park, which combine to account for the bulk of the faunal biomass in the reserve ecosystem. Among the larger mammals include elephant population, hippos, buffalos, antelopes, warthogs, baboons, et cetera (Briggs, 2007). Carcasses of these common animal species are tracked for bush meat, although monkeys and rodents are the most common.

\subsection{Problem diagnosis}

The researcher focused on problems associated with how communities effectively participate in management of wildlife resources at Mole National Park. The main problem identified is about how inhabitants around the park illegally hunt for meat. They are usually either arrested or even shot and killed. Another problem is how the park has taken over all fertile agricultural lands which could have supported lucrative farm ventures without paying any compensation to the local communities. Upon interaction with various communities, individuals are motivated and expresses joy to become stake holders in the management of the park's resources. The research questions were to find out the following:

i. will the community participatory approach address the issue of declining wildlife population in the park?

ii. will the community-based approach strategy ensure a sustainable wildlife management system in the area and therefore reduce conflict?

iii. will the strategy contribute to the improvement of community livelihood sustenance?

\subsection{Purpose and specific objectives of the study}

The general objective of the study was to assess the impact of participatory community-based wildlife management strategies in the conservation of wildlife resources at Mole National Park, Ghana. The specific objectives were to: 1 . Identify the current wildlife management strategies through the involvement of the local communities. 2. Assess roles or responsibilities of local people towards management of wildlife resources by the people. 3. Identify the benefits derived from the park wildlife resources by buffer zone communities. 


\subsection{Significance and Scope of the Study}

The research work was basically meant to help communities around the Mole National Park appreciate the need for their involvement in management of the wildlife resources for present benefits and posterity (Forestry Commission Act, 1999). Connectively, the findings benefit the target communities despite that other communities can also adopt the recommendations. The report serves as a resourceful reference material to other researchers on parks and wildlife issues for drawing key lessons on best practices on wildlife management, park resource conservation or sustainability and game-trademarket-value chain promotion.

\section{Brief literature review}

Literature helps identify options for scientific and appropriate execution of the park resource management strategy which hugely rely of biodiversity conservation and sustainable land use management (Stuart \& Adams, 1990). Mole National Park is Ghana's largest recreational wildlife resource base, located in North-West of Ghana on grassland Savanna and riparian ecosystem at an elevation of $150 \mathrm{~m}$, with sharp escarpment forming the southern boundary of the park. The park's entrance is reached through the nearby village of Larabanga. The Lovi and Mole rivers are ephemeral rivers flowing through the park leaving behind only drinking holes during the long dry season. This area of Ghana receives over $1000 \mathrm{~mm}$ per year of rainfall. A long-term study has been done on Mole National Park to elucidate the impact of human activities (Kuuder et al., 2013). The park's lands were set aside as a wildlife refuge in 1958. In 1971 the small human population of the area was relocated and the lands were designated a national park. The park has not seen any major development as a tourist location since its original designation. The park as a protective area is underfunded and national and international concerns exist about poaching and sustainability, but protection of important resident antelope species has improved since its initial funding as a preserve. The park is an important study area for scientists because the removal of the human population from it permits some long-term studies, in particular, of relatively undisturbed sites compared to similar areas of densely populated equatorial West Africa (Sindinga, 1995). One study shows a resident population of eight-hundred (800) elephants at Mole (Kuuder et al., 2013).

\subsection{Flora}

Some tree species within Mole reserve include Burkea Africana, Isobedinia doka and Terminalia macroptera. The savanna grasses somewhat low in diversity but known species include a spikesede, Kyllinga echinata, Anerlema setiferum var pallidicliatam and two endemic members of the Asclepiadeceae subfamily, the vine, Gongronema obscurum, and the edible geophytes, Raphionaome vignei. The commonest trees within the Mole park known by their scientific names to the respondents includes: Adansonia digitata, Afzelia africana, Anogeissus leicarpus, Afraegle paniculate, Burkea Africana, Butyrospermum paradoxum, Cassia sieberana, Celastrus senegalensis and Combretum ghasalense. The shrubs included: Diospyros mespilifomis, Feretia apodathera, Flueggea virosa, Tinnsea spp, Urginea spp (Sobey,1978). The Herbaceous plants listed were- Abutilon ramososum, Aneilema umbrosum, Atylosia scarabaeoides, Btepharis maderaspatensis, Desmodium velutinum, Mariscus altemifolius, Ruelia, Sida urens, Triumfatta pentadra and Wissadula amplissima. The grasses also included-Andropogon spp including Andropogon gayanus var squamulatus (a tall grass), Brachiara spp, Loudetiopsis kerstingic, Sporobolus pyramidalis (only in protected areas) and Setaria barbata (only in protected areas) (Kuuder et al., 2013b).

\subsection{Fauna}

The park is home to over 93 mammal species, and the large mammals on the park include an elephant population, hippos, buffalo and warthogs. The park is considered a primary African preserve for antelope species including kob, Defassa waterbuck, roan, hartebeest, oribi, the bushbuck, and two duikers, the red duiker and the yellow-backed duiker (East, 1999). Olive baboons, black and white Colobus monkeys are the known species of monkey resident in the park. Of the 33 known species of reptiles, slender-snouted and dwarf crocodiles are found in the park. Sighting of hyenas, lions and leopards are unusual, but these carnivores were once more common in the park (East et al., 1989). Among the 344 listed birds species are the martial eagle, the white-headed and palmit vultures, saddle- 
billed storks, herons, egrets, the Abyssinian roller, the violet turaco, various shrikes and the red-throated bee eater Mole National Park, like other Ghanaian game reserves is poorly funded for prevention of poaching (Shaw, 2018). Poachers tend to live within 50km of the boundaries of the park. This distance of $50 \mathrm{~km}$ is the reported greatest distance hunters were willing to travel with poached game. The remnant human population of the park was removed in 1961, leaving all game hunters outside of the reserve meaning that mammal populations on the edges of the park are impacted more by hunting than the interior populations. This happens to be the reason why residents around the park resort to hunting rather that farming as their major means of survival (Kuuder et al., 2013b).

\section{Research methodology}

\subsection{The study area and target population}

The area of study is West Gonja District of the Northern Region within which the Mole National Park is located in northwest Ghana on grassland savanna and riparian ecosystem at an elevation of $150 \mathrm{~m}$, with sharp escarpment forming the boundary. It is being surrounded by several villages. The target population for this study was residents around the Mole National Park (GSS,2005). Since the number of communities sharing boundaries with the park are numerous, the sampling villages were randomly chosen out of which respondents were also randomly selected.

\subsection{Research design, approach and ethical consideration}

The research was designed using the bottom-up approach whereby participants were selected from almost all the communities at the buffer zones of the park irrespective of their educational levels once they had some familiarity pertaining to activities of the Park and could suggest valid responses. Only respondents who had lived in these communities between 6 months and 2 years and were concerned with the issues of the park were contacted alongside some opinion leaders such as Assembly men. Ethically, the study did not involve handling of any invasive species, wild animal or toxic chemical and all surveys and movements within the park environs where wild animals might be encountered were assisted by trained Range Officials or Park Guards to avoid mayhem. Besides, the Park management staff controlled the approved time schedules for proper conduction of the survey and provided relevant reference literature and orientation to the participants. The subjects were also permitted to ask relevant questions to clarify their doubts before the study began. All the questionnaire items were pretested to validate its veridicality, and scored $>97 \%$ valid- response rates from each community respondent. This demonstrated that they were actually ready and able to suggest answers to almost all the structured questions before the main survey was executed. Besides, the data collected were analyzed at the level of simple descriptive statistics to ease interpretation and application or adoption of the key findings by relevant stakeholders of wildlife management for well-informed, follow-up decision making.

\subsection{Sampling methods, data collection instrument and questionnaires administration}

Due to limited time and financial constraints, all the towns/villages in the study area could not be covered. The simple random sampling was then used to select three (3) villages where interactions were made. These villages include Murugu (a population of about 1,000 people), Larabanga (a population of about 4,000 people) and Kabampe (with a population of about 900 people) (GSS, 2005). With regards to the number of respondents to be contacted in each town/village, random sampling was used to select a total of sixty (60) residents, twenty (20) from each town or village. The instrument developed and used to obtain data for the study was questionnaire supplemented with interviews, local historical documentation and discussions. The literate among the sixty randomly selected respondents were given the questionnaires to complete within two weeks. Those who could not read and write were however assisted by the literates. Options were provided in the questionnaire for respondents to independently suggest valid answers. Simple written responses were done on few items. Initially respondents were tempted to reject the questionnaires because there was a high suspicion level that it could possibly be another plot similar to that of the forced evacuation of some villages from the park in 1964 (Danso \& Mason, 1993). The percentage recovery rate was $100 \%$.

\subsection{The case of Murugu}

Murugu is a "hanga" or historic village on the southeast border of the Mole National park in which the research was carried out around the three communities. Although unique, Murugu typifies 
many of the other communities around the park. The people lost significant farmlands during the formation of the reserve. In 1957 and again in 1969 the boundary line was moved to enclose larger portions of the land. Unlike the six evacuated communities, the village has never been moved. Their assumption, following the reconnaissance visit was that Game and Wildlife Department (GWD) was about to assess what would be required to move the village so that the park could be further expanded. Thus, on a second visit there was a difficult situation. This frustration was as a result of the old suspicion that the survey might be tailored for GWD but the researchers were able to verbally motivate a village elder to narrate the historical relation between the village and the park through the creation of the reserve and its ongoing management strategies. During the narration some sensitive issues were noted which needed to be addressed. The village was most upset about the park emphasizing that majority of their gods had been left inside the park and that they were denied access to perform regular sacrifices among other rituals, and felt that these deities were rather unhappy with them and hindering their prosperity. They further hinted that poor harvests, diseases, poverty and unexpected conflicts were the effects of neglecting their sources of spiritual protection otherwise derivable from the Park.

\subsection{Data analysis}

The raw data were analyzed using Statistical Package for Social Sciences (SPSS Chicago version 16.0) software at the level of simple descriptive statistics for easy interpretation of the findings by stakeholders. The frequencies of responses were transformed into percentages and fundamentally presented in tabular forms for easy interpretation of citizens, community development partners and public readers who may wish to adopt the findings for further decision-making purposes. The descriptive method was used to convert the data frequencies into percentages and averages of the variables used in the study.

\section{Results and discussion}

4.1 Demographic characteristics of the respondents

Table 4.1: Gender, age distributions and educational status of the respondents

\begin{tabular}{lll}
\hline Sex & Frequency & Percentages $\mathbf{\%})$ \\
\hline Male & 50 & 80 \\
Female & 10 & 20 \\
Total & $\mathbf{6 0}$ & $\mathbf{1 0 0}$ \\
\hline Age distribution of respondents & & \\
\hline 21-30 years & 22 & 36.67 \\
31-40 years & 24 & 40.00 \\
41-50 years & 10 & 16.67 \\
> 50 years & 4 & 6.66 \\
Total & $\mathbf{6 0}$ & $\mathbf{1 0 0}$ \\
\hline Educational status of respondents & & \\
\hline Basic Education & 14 & 23.30 \\
GCE/O/A/SSSCE & 20 & 3.30 \\
Training College & 0 & 0.00 \\
Other Tertiary (University, Polytechnic) & 0 & 0.00 \\
Non-formal education & 26 & 43.40 \\
Total (N=60 respondents) & $\mathbf{6 0}$ & $\mathbf{1 0 0}$ \\
\hline
\end{tabular}

The data in table 4.1 shows the background of respondents. The background of the sixty (60) respondents shows that eighty percent $(80 \%)$ were males as against twenty percent $(20 \%)$ females. About $36.67 \%$ of the respondents/inhabitants were in the age group of $21-30$ years, $40 \%$ between 31 40 years, $16.67 \%$ within $41-50$ years and $6.66 \%$ aged 51years and above. It has been keenly observed by Broskleby (1996) that the user group-market-value chain for wildlife produce does not exclude hunters or poachers who undoubtedly engage middlemen who sell their game to pepper soup dealers and the chop bar operators financing them to poach. Meanwhile, past documented state-space models have much recently confirmed continuing elephant poaching problem in most parts of Africa that is threatening the sustainability of this endangered species for wildlife and eco-tourism sustainability 
functions (Buckland et al., 2004). The report also advanced that, using the state-space model, for 20112020 figures suggest that the youth may be actively involved in farming and hunting activities since the mean age of the respondents was 38.5 years. The aging group however may not be actively involved. The data in table 4.1 further presents the educational status of the respondents. It shows that, $23.3 \%$ of respondents had basic education and 33.3\% attained GCE/O/A/SSSCE education while up to $43.4 \%$ lacked formal education. This authenticated that the level of education of the majority of respondents was generally low. Hence, they may find it uneasy to fight for their right and or take up higher level management responsibilities at the reserve, since higher standard of education contributes to change of social behavioral status through mental empowerment to render various services towards national development. In addition, it is an undisputed fact that well educated persons will always request for what is due them and as well be more responsible (Ladner \& Gbadegesin, 1996).

\subsection{Occupations and types of tools used for task execution}

Table 4.2 Occupation, types of hunters, hunting and basic farming tools identified by the respondents

\begin{tabular}{lll}
\hline Occupation & Frequency & Percentages (\%) \\
\hline Farmer & 20 & 33.00 \\
Hunter & 4 & 6.70 \\
Both & 36 & 60.00 \\
Total & $\mathbf{6 0}$ & $\mathbf{1 0 0}$ \\
\hline Types of hunters & Frequency & Percentages (\%) \\
\hline Licensed & 9 & 15 \\
Poacher & 45 & 75 \\
None & 6 & 10 \\
Total & $\mathbf{6 0}$ & $\mathbf{1 0 0}$ \\
\hline Hunting tool & Frequency & Percentage \\
\hline Traps & 23 & 38.30 \\
Shotguns & 2 & 45.00 \\
Rifles & 4 & 6.70 \\
None & 6 & 10.00 \\
Total & $\mathbf{6 0}$ & $\mathbf{1 0 0}$ \\
\hline Types of basic farming tools & Frequency & Percentage (\%) \\
\hline Hoe & 35 & 58.30 \\
Cutlass & 24 & 40.00 \\
None & 1 & 1.700 \\
Total (N=60 respondents) & $\mathbf{6 0}$ & $\mathbf{1 0 0}$ \\
\hline
\end{tabular}

The data in table 4.2 shows the occupations of respondent and the type of tools they use to accomplishments. Only $6.70 \%$ of respondents were involved in hunting but $33.30 \%$ were into farming and as many as $60 \%$ were involved in both farming and hunting. This suggest that the resident communities could not rely on farming alone since there was limited fertile lands left for them and their inability to have access to certain herbal plants in the park to enable them prepare medicines for sale served as an outstanding disadvantage. This highlights their level of deprivation. And in order to alleviate poverty, the people then resorted to hunting animals which intruded their farms also ventured into secluded areas of the reserve to poach leading to elephants attacking and wounding some poachers. A recent incident was observed and reported by the Mole Park authorities (Report of Bole-based Nkiligi FM, 2019). This phenomenon confirms the point raised in 2018 that, no significant temporal trends was found in rates of illegal killing for Southern, Central and Western Africa. Only in Eastern Africa have poaching rates decreased substantially since 2011. For Africa as a whole, poaching did decline for 20112018, but the decline was entirely due to Eastern African sites (Schlossberg et al., 2020). The results further suggested that poaching for ivory has not diminished across most of Africa since 2011 and elephant populations have continually faced crises from critical assessments in different parts of the world (UNEP, CITES, IUCN \& TRAFFIC, 2013).

Further analyses showed that $38.30 \%, 45 \%$ majority and $6.70 \%$ respondents opined that hunters used traps, short guns and rifles respectively for hunting while $10 \%$ were or unfamiliarized with or 
disassociated from hunting related activities (Table 4.2). The use of traps and short guns dominated because these hunting devices were less expensive and accessible compared to rifles which are more expensive or difficult to obtain. The $10 \%$ of respondents who do not use any of these hunting devices were either not prepared to acquire it or uninterested in the job. The data in Table 4.2 further illuminates the types of farming tools used by the surrounding communities that engaged in farming. It is clear that $58.3 \%$ majority of the respondents used simple farm tools (hoes) and $40 \%$ cutlasses, while $1.7 \%$ were not into farming. The main reason advanced for farming was to secure money or food through farming related economically sustainable livelihood ventures to improve their living standards. The few nonfarming respondents intimated they found it very difficult to secure two square meals. The report further indicates the type of hunters encountered in the survey. As much as, $15 \%$ of the valued hunters were licensed according to the respondents while $75 \%$ majority were poachers who infringed the regulations enforced by the Game and Wildlife Department personnel and $10 \%$ were not atypically hunters because they felt the act was extremely risky and muscular driven. Enforcement of regulations and byelaws against illegal hunting have generally been exploited as good alternatives for safeguarding wildlife and endangered species populations (MSPCA-Angell, 2020), even though, the aspersions cast by virulent recalcitrant poachers denigrate the usefulness and effectiveness of the process in formal wildlife adventures.

\subsection{Peak season of wild animal encounter at the Mole Park vicinities}

Table 4.3: Peak seasons of animals hunting, why certain animals are allowed for hunting at all times and the methods of fishing adopted by the adjoining communities

\begin{tabular}{|c|c|c|}
\hline Period & Frequency & Percentages $(\%)$ \\
\hline January-April & 2 & 3.30 \\
\hline May-August & 13 & 21.70 \\
\hline September-December & 45 & 75.00 \\
\hline Total & 60 & 100 \\
\hline $\begin{array}{l}\text { Reason why certain animals are allowed for all year- } \\
\text { round hunting }\end{array}$ & Frequency & Percentages $(\%)$ \\
\hline $\begin{array}{l}\text { Proliferates to higher (excess) populations, because it has } \\
\text { high prolificacy index or shorter gestation periods. }\end{array}$ & 37 & 61.70 \\
\hline Destroy farm produce and are seen as nuisance by farmers & 23 & 38.30 \\
\hline Total & 60 & 100 \\
\hline $\begin{array}{l}\text { Reasons why certain animals are not allowed for all year- } \\
\text { round hunting }\end{array}$ & Frequency & Percentages $(\%)$ \\
\hline $\begin{array}{l}\text { Not prolific breeders with longer gestation periods and or } \\
\text { getting extinct. }\end{array}$ & 56 & 93.30 \\
\hline $\begin{array}{l}\text { Numerically scarce, or may even be abundant but are } \\
\text { strictly preserved due to its unique ecosystem roles or } \\
\text { functions in the food web as it may constitute the sustenance } \\
\text { for carnivores that intend feeding on them to create } \\
\text { ecological balance, and if they are not been destructive or } \\
\text { threat posing to human properties and farms around. }\end{array}$ & 4 & 6.70 \\
\hline Total & 60 & 100 \\
\hline Fishing method or tools used & Frequency & Percentages $(\%)$ \\
\hline Use of chemical (DDT) & 25 & 41.60 \\
\hline Nets & 15 & 25.00 \\
\hline Hook & 10 & 16.70 \\
\hline None & 10 & 16.70 \\
\hline Total (N=60 respondents) & 60 & 100 \\
\hline
\end{tabular}

The peak season of hunting in the Mole Park, why certain animals are allowed for hunting at all times whilst others are not and the methods of fishing adopted by the communities are presented (Table 4.3). January-April in the dry season was indicated by $3.30 \%$ of the respondents as the usual time wild animals run deep into the reserve. In effect, a few are spotted in the park. But, during May- 
August in the rainy season when forbs and grasses begin to grow for the animals to feed and procreate, their numbers spotted increase up to about 21.70\%. Between September and December when there are abundant feeds, undisturbed animals with low gestation periods proliferate to about $75 \%$ occupancy for easy encounter in the park. It was further clearly elucidated that certain animals such as antelopes, grasscutters, squirrels, monkeys, and rats easily populate to $61.70 \%$ (Table 4.3 ). Hence such prolific breeders were allowed for hunting at all times. This management strategy is found to be in tandem with ecological balance/sustenance principle of maintaining carrying capacity for optimalization of productivity as recommended by Dyke (2003) in his book on conservation biology, foundations, concepts and applications at Wheaton College in the United States.

Contrarily, about $38.30 \%$ of the respondents believe the animals were hunted at all times as an intervention against destructions caused to farm produce. This implied, hunters could even illegally penetrate the reserve. It was clearly demonstrated why hunting of certain animals are not allowed at all seasons in the park in table 3. Up to $93.30 \%$ of the respondents opined it was to prevent endangered species of wildlife from extinction. Elephants were exclusively mentioned by the respondents as one of the endangered and strictly protected species since it has long gestation period of about twenty-two months with only one calf at most once in every five years. However only $6.7 \%$ of respondents affirmative the practice was a good population control measure based on the assumption that the elephants were still abundant, and the Department of Game and Wildlife had rather adopted an irrelevant restriction on elephant hunting. But emphatically, the Forestry Commission and Ghana Wildlife Society refutes this claim with the classical point of definition of the African elephant otherwise known as Loxodonta africana as a critically endangered species for conservation under the 1999 Forestry Commission's Act (Act 571) of Ghana. The data further presents the method of fishing adopted in communities around the Mole National Park (Table 4.3). Clearly observed, $41.6 \%$ of the subjects used chemicals to pollute water bodies for bumper fish harvest thereby, risking the lives of both human and animals alike who are dependent on the water resources for sustenance. In addition, $35 \%$ and $16.7 \%$ of fishermen respectively opted for use of net and hook as the acceptable methods of fishing according to the GWD fishing policy regulations enforced at Mole National Park enclave. About $16.7 \%$ respondents most of whom were females never engaged in fishing since it has generally been considered that males dominated the occupation because of its high muscular operational requirements even though, majority of the women engaged in fishery sector entrepreneurial ventures $(\geq 70 \%)$ also participate effectively in artisanal fish smoking, salting, drying packaging and distribution to various market centers in Africa (European Commission, 2015).

4.4 Arrests of park offenders, settlement of disputes and the disciplinary measures enforced by park authority

Table 4.4: Arrests and handling of park offenders, disciplinary measures in dispute resolution, community engagement in conflict resolution and how communities benefit from park resources.

\begin{tabular}{|c|c|c|}
\hline Arrests & Frequency & Percentages $(\%)$ \\
\hline Yes & 29 & 48.3 \\
\hline No & 31 & 51.7 \\
\hline Total & 60 & 100 \\
\hline Mode of settlement of cases of arrests & Frequency & Percentages $(\%)$ \\
\hline $\begin{array}{l}\text { Released freely if offence is minor and based on } \\
\text { justifiable evidences of little harm or damages posed }\end{array}$ & 13 & 21.70 \\
\hline Sent to court and charged & 17 & 28.30 \\
\hline Sent to court but discharged & 3 & 5.00 \\
\hline Imprisoned & 5 & 8.30 \\
\hline None & 22 & 36.70 \\
\hline Total & 60 & 100 \\
\hline $\begin{array}{l}\text { No. of persons killed by Wildlife Department on cases } \\
\text { of offences apprehended at one particular time }\end{array}$ & Frequency & Percentages $(\%)$ \\
\hline $1-5$ & 57 & 95.00 \\
\hline $6-10$ & 1 & 1.70 \\
\hline $11-16$ & 2 & 3.30 \\
\hline
\end{tabular}




\begin{tabular}{|c|c|c|}
\hline $\begin{array}{l}16+ \\
\text { Total }\end{array}$ & $\begin{array}{l}0 \\
60\end{array}$ & $\begin{array}{l}0 \\
100\end{array}$ \\
\hline $\begin{array}{l}\text { Rate of interaction or dialogue between park } \\
\text { authorities and communities towards settlement of } \\
\text { wild life related conflicts }\end{array}$ & Frequency & Percentages $(\%)$ \\
\hline Always (constantly) & 4 & 6.70 \\
\hline Occasionally (Often) & 56 & 93.30 \\
\hline Not at all & 0 & 0 \\
\hline Total & 60 & 100 \\
\hline $\begin{array}{l}\text { Extent to which respondents directly benefit from } \\
\text { proceeds of Game and Wildlife Department in the } \\
\text { buffer communities affected due to the park's } \\
\text { establishment. }\end{array}$ & Frequency & Percentages (\%) \\
\hline (Yes)-have benefitted much from the park's resources & 53 & 88.30 \\
\hline (No)- have not befitted much from the park's resources & 7 & 11.70 \\
\hline Total $(\mathrm{N}=60$ respondents) & 60 & 100 \\
\hline
\end{tabular}

Mode of settlement of cases with disciplinary measures enforced by park authority upon arrests of offenders and the extent of park authority involvement in dispute settlement and the extent of community engagement in dialogues is presented (Table 4.4). About $51.70 \%$ of respondents could not disclose known cases of arrests at the reserve while $48.3 \%$ confirmed their knowledge about confirmed arrests as a result of either illegally fishing or poaching in the reserve. The views of respondents on the mode of case settlement and actions/sanctions issued against park offenders and wildlife conflict issues indicated that $21.70 \%$ of culprits were arrested and released possibly due to negligible offences while $28.30 \%$ prosecuted and fined at a cost in court as deterrent punishment. Additionally, about $5.00 \%$ of those prosecuted were later on discharged for having been caught in the reserve but not committed any crime while $8.30 \%$ were not imprisoned for committing crimes such as poaching wild animals, fishing with explosive chemicals. The subjects indicated that about $36.7 \%$ of the community members had never been arrested for poaching or fishing illegally. About $95 \%$ of subjects attested it was 1-5 poachers been abducted in the reserve

\subsection{Responsibilities of the local people towards sustainable wildlife management}

Table 4.5: How wildlife conflicts are resolved in the community and the specific roles played by various community actors towards sustainable wildlife resources management.

\begin{tabular}{|c|c|c|}
\hline $\begin{array}{l}\text { Alternative Method of conflict resolution at Mole Park } \\
\text { Environs }\end{array}$ & Frequency & Percentages $(\%)$ \\
\hline Through the court systems & 33 & 55.00 \\
\hline Through local mediation & 7 & 11.67 \\
\hline Interventions of Community Chiefs & 20 & 33.33 \\
\hline Total & 60 & 100 \\
\hline $\begin{array}{l}\text { Specific roles played by community actors towards } \\
\text { sustainable wildlife resources management }\end{array}$ & Frequencies & Percentages $(\%)$ \\
\hline Administration of bye-laws & 2 & 3.3 \\
\hline Prevention of poaching & 1 & 1.7 \\
\hline Bush fire control & 11 & 18.3 \\
\hline $\begin{array}{l}\text { Community watchdog patrols against unauthorized } \\
\text { exploitation of wildlife resources }\end{array}$ & 5 & 8.3 \\
\hline $\begin{array}{l}\text { Administration of taboos, totems and beliefs on certain } \\
\text { wildlife artifacts }\end{array}$ & 41 & 68.4 \\
\hline Total (N=60 respondents) & 60 & 100 \\
\hline
\end{tabular}

The responsibilities of the local people towards the sustainable management of wildlife resources in the communities around Mole Park through alternative conflict resolution methods are further demonstrated alongside the specific roles played by communities towards sustainable wildlife 
resources management (Table 4.5) It well clarified that most of the wildlife conflicts were settled in the law courts since $55 \%$ attested to this claim. Only $11.67 \%$ of respondents opined arising conflicts had often been settled through mediation while as much as $33.33 \%$ attributed successful mediation as a credit to while 1-70\% believed 6-10 people have been killed, 3.30\% opined about 11-15 of offending poachers were killed, while no one accepted that 16 or more persons were ever killed at one time for flouting park regulations. It presupposes the abductees were actual perpetual and hardened poachers who had previously escaped arrest and may have probably threatened wildlife guards under cover of darkness or armament with sophisticated weapons. Some notorious poachers were assumed to be armed robbers at the peripheries of the park, been previously involved in court cases or sentenced to imprisonment and later released (Report of Bole -based Nkiligi FM, 2019). The notoriety of poachers in reserves and riverine areas in West Africa were earlier discovered under the Capacity Development of the West Coast Wildlife Management Committee Moun Cameroun Project (Ekwoge et al., 1998; Abonge, 1999).

The data again indicated the frequency of interaction between personnel of the Game and Wildlife Department and adjoining communities to the Mole National Park was about $93.30 \%$ frequent because the Park management prioritized such dialogues to conscientize indigenes on the need to refrain destructive anthropogenesis such as bush firing, poaching or illegally hunting of reserved wild life so as to address attendant conflicts. Some $6.70 \%$ of the subjects considered the interaction as somewhat infrequent. Table .44 data elucidate the direct benefits derived from the Game and Wildlife Department by affected communities that had been relocated in the course of the park establishment. It clearly revealed that $88.30 \%$ the affected members benefited from the park's social intervention programs in terms of supply of bee keeping tools and free training on honey harvesting and processing to augment their income. However, $11.70 \%$ subjects were uncertain that apiculture could secure them tangible benefit as against their expectations about the many foregone options of illegally poaching of wild animals to gain quick money from the sale of ivory and game. chiefs of communities adjacent to Mole. The positive impacts of traditional leaders in wildlife and land use conflict resolutions can never be overlooked since it inculcates peaceful dialogues (Emanuel \& Ndimbwa, 2013). These modes of conflict resolution suggest lack of cordial relationship between the community actors and park management in terms of fostered mutual participation in the adoption of communal bylaws towards conflict resolution (Chigas \& David, 2006). It was ascertained that the communities play inclusive roles towards management of the wildlife resource to prevent depletion. For instance, $68.4 \%$ respondents pointed attachment of taboos and totems to certain wildlife artifacts as adaptive measures that effectively promulgated the good will of the people to guard and protect the reserve from depletion by illegal hunting and poaching persistence. Also, the act of controlling wild fires and desisting from farming within reserved and protected areas were additional behavioral change practices suggested. The Kamara's of Larabanga for instance, consider the elephant as a totem and as such, do not kill or even eat it similar to what pertains in Democratic Republic of Congo where the fight against elephant poaching has been intensified (Hammer \& Muller, 2016). This intervention allows the elephant population to increase in woody vegetation (WWF, 2007; Sackey \& Hale, 2008). Again 3.3\% of the respondents were affirmative in their resolve to adapt park administrative bylaws that regulate adjoining communities and punish offenders. Whiles about $1.7 \%$ of the respondents sided with adopting antipoaching measures, about $18.3 \%$ on the other hand indicated need for anti-bush fire campaigns, and 8.3\% expressed their willingness to serve as community watchdogs/patrols towards fighting illegal exploitation of wildlife resources. It is anticipated that adapting the concept of community watchdog/patrol teams will significantly curtail the incidence of over exploitation and minimize emerging and existing wildlife conflicts between the park management workers and buffer zone communities (Gbimire, 2019; White \& Ward, 2011). Successful negotiations could even play a significant role in balancing the needs of people and wildlife when wildlife damage crops or prey on livestock (Treves, 2007).

\section{Conclusion}

The study investigated the impact of community participation in adaptive wildlife management at Mole National Park in the west Gonja District of the Northern Region. The results revealed that $80 \%$ of the respondents were males and $43.30 \%$ of them lacking formal education. Roughly $60 \%$ of the 
subjects were both into hunting and farming. About 5\% majority of hunters in these communities used traps and short guns for hunting since they are somewhat cheaper and relatively accessible. Additional $38.30 \%$ to $45 \%$ of the subjects posited on the use of traps and short guns to hunt. Subsistence farmers in the communities resorted to the use of simple farm implements, about $58.30 \%$ and $40 \%$ respectively used hoes and cutlasses. Prolific breeding monkeys, rats, antelopes, warthogs, antelopes, francolins, et cetera were allowed for hunting outside the park whiles elephant were strictly disallowed due to its low prolificacy and longer gestation periods.

The interaction of wildlife officials with community member is only occasional but this does not create avenue for the communities to make their inputs as to how the park should be ran on frequent basis. About $93.3 \%$ of respondents opined that the wildlife officials ought to enlighten them occasionally on norms of the park. Benefits derived by adjoining communities from the park management as part of corporate social responsivities included established bee keeping projects for some members of the communities to manage by applying modern techniques (about $88.30 \%$ of respondents attested to this fact. Most wildlife management conflicts were resolved in the law court with few cases of mediations by traditional chiefs. This conflict resolution approach phenomenally heightened arising tempers between park management and communities, consequently causing some dreads among members who considered their opponents as enemies they could shoot and kill at the least provocation. About $95 \%$ of respondents revealed that at least 1-5 person(s) had been killed by personnel of the park as while 55\% disclosed that conflicts were mainly settled through the court system. Generally, it was observed that as high as $68.4 \%$ of respondents in the communities contributed towards protecting the wildlife resources by administering taboos, totems and beliefs on certain animals of the reserve for sustainable national development through eco-tourism.

Emerging from the results and discussion, it was clearly pointed that most of the respondents were of low educational background as the illiteracy rate was high among indigenes. Most peasant farmers were dependent on traditional hoes and cutlasses for cultivation on small acreage infertile soils since the fertile lands have been engulfed by the park. Lack of access to farm lands compels some recalcitrant farmers to encroach the park, leading to situations whereby wild animals are destroying crops and farm produce thereby provoking farmers who consequently poached them. The farm destructions by wild animals versus poaching subsequently engendered a lot of conflicts between the park's management and community members. But, communities in their own wisdom have historically administered taboos, totems and beliefs on certain wildlife artifact which must practically be reinforced by introducing adaptive byelaws. The study generally proved that regardless enacting laws or regulations, inclusive local community participation in sustainable conservation decision making is an innovation that will trigger positive impacts.

\section{Recommendations}

i. The communities around Mole national park have been made over the years to feel that they only have a negative impact on conservation and do not have much to offer the Game and Wildlife Department. Participatory rural appraisal should be used from time to time to build confidence and selfappreciation for contributions of the community members which could play key roles towards protecting the wildlife resources.

ii. The communities within the park buffer zones should be invited to make input into management planning prospective future of the park. The current trend towards involving local people in protected area management can only work when peoples are empowered through initiation of alternative livelihood and capacity building programmes.

iv. Management/Government should help the community members educate their children to access employment within the Game and Wildlife Department to supporting management of the park since they are already abreast of the Park history and could as well juxtapose their local problem-solving skills. Irrigation dams should be engineered for the inhabitants to practice dry season farming instead of poaching wild animals for alternative livelihoods. 


\section{Limitation}

The research should have covered most villages at the peripheries of Mole National Park environs in order to upscale extensive investigations for higher detailed findings. Unfortunately, funds and time needed for such an assignment were not adequately available to the researchers. Consequently, the survey was limited to about 60 participating respondents. In spite, these limitations were virtually overcome to some extent since 3.3\% and 23.3\% of them were either Senior High or Basic School literates. The $43 \%$ who were non-formally educated were guarded by the literate counterparts to suggest valid responses to the already pretested questionnaires within two weeks. Options were provided in the questionnaire for respondents to select "Yes" or "No" simple written responses. Also, the temptation to reject the questionnaires on the suspicion of previous force evacuation plots against villages around the park as pertained in 1964 (Elijah \&John, 1993) was later refuted and the recovery response rate was $100 \%$.

\section{Acknowledgements}

The authors are grateful to the Assembly Man at Laribanga and the Mole National Park Management for volunteering to help in the questionnaire responses during the community survey.

\section{Authors' Contributions}

Benjamin provided leadership guidance, expertise and funding to conduct the research with Braimah and Richard. Vida, Ernestina and Elisha reviewed aspects of the literature and updated references. All authors contributed financially and co-edited the article.

\section{References}

Abonge, G. (1999). Capacity development of the West Coast Wildlife Management Committee. Moun Cameroun Project.

Ambrose-Orji, B (1997). Forest livelihood implications for biodiversity conservation. Mount Cameroun project, Limbe Cameroun.

Brashares, J. S., Arcess, P., Sam, M. K. (2001). Human demography and reserve size predict wildlife extinction in West Africa.

Briggs, P. J. (2007). Ghana $4^{\text {th }}$ Bradt. Travel guide. Perfect, Revised Edition. eBay Inc. https://www.ebay.com/p/59011841.

Broskleby, M. A. (1996). User group analysis for participatory forest management. West Coast. Mount Cameroun Project.

Buckland, S. T., Newman, K. B., Thomas, L. \& Koesters, N. B. (2004). State-space models for the dynamics of wild animal populations. Ecol. Model. 171, 157-

175, https://doi.org/10.1016/j.ecolmodel.2003.08.002

Chigas, D. and David, F. (2006). Alternative dispute resolution workshop report. Washington D.C.

Danso, E. Y. and Mason, J. J. (1993). Participatory rural appraisal Mole National Park Ghana.

Dyke, F. V. (2003). Conservation Biology, Foundations, Concepts and Applications. McGraw- Hill companies Inc., Avenue of the Americas, New York, NY 10020 174-200.

East, R. (Rod) (1999). African Antelope Database 1999. Gland, Switzerland.

East, R. (Rod), Mallon, D.P. (David P). Kingswood, S. C. (1989). Antelopes: global survey and regional action plan. Gland, Switzerland International Union for conservation of Nature and Natural Resources.

Ekwoge, E. Ntube, G, J. M. Acworth, J. (1998). Mokoko River Forest Reserve. User Group Analysis (UGA) for sustainable wildlife management. Mount Cameroun Project.

Emanuel, M. \& Ndimbwa, T. (2013). Traditional mechanisms of resolving conflicts over land resource: a case of Gorowa Community in Northern Tanzania. International Journal of Academic Research in Business and Social Sciences November 2013, 3(11).

European Commission (2015). Fighting illegal fishing: Commission warns Taiwan and Comoros with yellow cards and welcomes reforms in Ghana and Papua New Guinea. http://europa.eu/rapid/press-release_IP-15-5736_en.htm

Forest Commission Act (1990). Forest Commission Act (Act 571) of Ghana. Summary of components. Date of Gc efte notification: 10th September. Pages 1-18. 
Gbimire, P. (2019). Analysis of human wildlife conflict in buffer zone area: a study from Chitwan National Park, Nepal. International Journal of Natural Resource Ecology and Management, 4(6), 164-172.

http://www.sciencepublishinggroup.com/journal/paperinfo?journalid=207\&doi=10.11648/j.ijnr em.20190406.12

Ghana Statistical Service (2005). 2000 population and housing census. Accra: Printing and Publications Section, GSS.

Hammer, J. Muller, P. (2016). The fight against elephant poachers is going commando. Smithsonian Magazine. June issue, supported by a grant from the Magnum Emergency Fund. https://www.smithsonianmag.com/science-nature/fight-against-elephant-poaching-goingcommando-180959071/

https://www.mspca.org/animal_protection/poaching/.

Kuuder, C. J. W., Bagson, E. \& Aalangdong, I. O. (2013). Livelihood enhancement through ecotourism; a case of Mognori Ecovillage near Mole National Park, Damongo, Ghana. International Journal of Business and Social Science, 4(4), 128.

Kuuder, C.J. W., Bagson, E., and Aalangdong, I. O. (2013b). Assessment of visitor satisfaction in Mole National Park, Ghana. African Journal of Hospitality, Tourism and Leisure, 2(3) - (2013) ISSN: 2223-814X.

Ladner, J. A. and Gbadegesin, S. (1996). Ethics higher education and social responsibility. Howard University Washington USA.

MSPCA-Angell (2020). Kindness and care for animals. Enforce of Illegal Hunting Practices. The MSPCA-Angell 501(c)(3) Non-Profit Registered in the US Under EIN:04-2103597.

Report of Bole-based Nkiligi FM. (2019). Elephant attacks poacher at Mole National Park. General News of Monday, 17 June 2019. Source: My News GH. https://www.ghanaweb.com/GhanaHomePage/NewsArchive/Elephant-attacks-poacher-atMole-National-Park-755696

Rilley, W. and Rile, L. (2005). Nature's Strongholds; the world's great wildlife reserves. http://www.barnesandnoble.com/w/natures-strongholds-the-worlds-great-wildlife reserveslaura-riley/1100021890

Sackey, T. and Hale, W. G. H. (2008). The impact of elephants on the woody vegetation of Mole National Park, Ghana.

Schlossberg, S., Chase, M. J., Gobush, K. S., Wasser, S. K. and Lindsay, K. (2020). State-space models reveal a continuing elephant poaching problem in most of Africa. Sci Rep 10, 10166 (2020). https://doi.org/10.1038/s41598-020-66906-w.

Shaw, E. (2018). Common wildlife in Ghana. Travel Tips, Leaf Group Updated March 21. https://traveltips.usatoday.com/common-wildlife-ghana-105823.html.

Sindinga, I. (1995). Wildlife-based tourism in Kenya: landuse conflicts and government compensation policies over protected areas. Journal of Tourism Studies, 6(2), 45-55.

Sobey, D. G. (1978). Anogneissus Groves on Abandoned Village Sites in the Mole National Park, Ghana. Biotropica 10(2), 28-38.

Stuart, S. N. \& Adams, R. J. (1990): Biodiversity in sub-Saharan Africa and its islands. Conservation, Management, and sustainable use. Occasional Papers of the IUCN Species Survival Commission No. 6, VI + 242 S., IUCN, Gland, Switzerland, ISBN 2-8317-0021-3. https://doi.org/10.1002/mmnd.19960430220

Treves, A. (2007). Balancing the Needs of People and Wildlife: When Wildlife Damage Crops and Prey on Livestock. J. People and wildlife. No. 7; August 2007.

UNEP, CITES, IUCN \& TRAFFIC. Elephants in the dust - the African lephant crisis. A rapid response assessment. United Nations Environment Programme, GRID-Arendal (2013).

White, P. C., and Ward, A. I. (2011). Interdisciplinary approaches for the management of existing and emerging human-wildlife conflicts. Wildl Res, 37, 623-629.

WWF. (2007). A case study on human-wildlife conflict in Nepal (with particular reference to humanelephant conflict in Eastern and Western Terai regions). World Wildlife Fund, Kathmandu, Nepal: pp 47-48. 